\title{
Nitrogen Source Preference and Growth Carbon Costs of Leucaena leucocephala (Lam.) de Wit Saplings in South African Grassland Soils
}

\author{
Nonkululeko Sithole $^{1}\left(\mathbb{D}\right.$, Zivanai Tsvuura ${ }^{2}$ (D), Kevin Kirkman ${ }^{2}$ (D) and Anathi Magadlela ${ }^{1, *(D)}$ \\ 1 School of Life Sciences, College of Agriculture, Engineering and Science, University of KwaZulu-Natal, \\ Westville Campus, Private Bag X54001, Durban 4000, South Africa; lulekosithole@gmail.com \\ 2 School of Life Sciences, College of Agriculture, Engineering and Science, University of KwaZulu-Natal, \\ Pietermaritzburg Campus, Private Bag X01, Scottsville 3209, South Africa; Tsvuuraz@ukzn.ac.za (Z.T.); \\ KirkmanK@ukzn.ac.za (K.K.) \\ * Correspondence: anathimagadlela@icloud.com; Tel.: +27-31-260-2076
}

\section{check for}

updates

Citation: Sithole, N.; Tsvuura, Z.; Kirkman, K.; Magadlela, A. Nitrogen Source Preference and Growth Carbon Costs of Leucaena leucocephala (Lam.) de Wit Saplings in South African Grassland Soils. Plants 2021, 10, 2242. https://doi.org/10.3390/ plants10112242

Academic Editors: Maria Cristina

Morais, Paula Lorenzo and

Maurizio Cocucci

Received: 24 August 2021

Accepted: 14 October 2021

Published: 21 October 2021

Publisher's Note: MDPI stays neutral with regard to jurisdictional claims in published maps and institutional affiliations.

Copyright: (c) 2021 by the authors. Licensee MDPI, Basel, Switzerland. This article is an open access article distributed under the terms and conditions of the Creative Commons Attribution (CC BY) license (https:// creativecommons.org/licenses/by/ $4.0 /)$.

\begin{abstract}
Leucaena leucocephala (Fabaceae) is native to Central America and has invaded many climatic regions of the tropics. In South Africa, the species is categorized as an emerging or incipient weed used as fodder, timber, firewood and in erosion control on degraded habitats. The species is common along the eastern subtropical regions of KwaZulu-Natal (KZN) Province, where it invades grasslands, savannas and edges of forests. Soils of these ecosystems are characterized as nutrient deficient and acidic. Using a pot trial, we determined the effects of the nutrient addition treatments on microbial symbiosis, $\mathrm{N}$ nutrition and biomass accumulation of L. leucocephala under greenhouse conditions. After 180 days of growth, plants were harvested, and their utilization of $\mathrm{N}$ derived from the atmosphere and from the soil was quantified through determination of $\delta^{15} \mathrm{~N}$ values. L. leucocephala maintained growth and $\mathrm{N}$ nutrition by relying on both atmospheric- and soil-derived $\mathrm{N}$ across all soil treatments. The NDFA was significantly higher in high P (N1 + P, N2 + P and N3 + P) soils. L. leucocephala was able to nodulate with intermediate and fast-growing strains from the Mesorhizobium and Rhizobium genus in N2 + P grown plants. This shows that L. leucocephala possesses traits that are successful in acquiring nutrients, especially in nutrient limited conditions, by establishing plant symbiosis with multiple bacteria and relying on extracting $\mathrm{N}$ from the soil and from the atmosphere through the symbiosis.
\end{abstract}

Keywords: emerging invasive; KZN soils; Leucaena leucocephala; $\mathrm{N}$ fixation; $\mathrm{N}$ and $\mathrm{P}$ deficiencies

\section{Introduction}

L. leucocephala (Lam.) de Wit (Fabaceae) is native to Central America and has been introduced in many geographic and climatic regions [1]. The species has been listed in the top 100 worst invaders of the world following deliberate introductions for agroforestry [1]. In South Africa, L. leucocephala is categorized as an emerging or incipient weed mostly occurring in the eastern subtropical parts of the country [2] made up of grassland, forest and savanna. However, most invasions have been noted in the savanna biome [3]. Savanna and grassland ecosystems provide multiple ecosystem services [4] and contribute to the rural and agricultural economy of South Africa in various ways [5], and the rural socioeconomy [6]. Therefore, sustainable management of plant biodiversity is an integral part of these ecosystems. South African savanna and grassland ecosystems are reported to be nutrient limited, especially with regards to nitrogen $(N)$ and phosphorus $(P)[7,8]$. In addition, the soils are also acidic [9]. Legume plants require $\mathrm{N}$ and $\mathrm{P}$ for various processes such as nodule growth and function [10]. Despite the nutrient limitations in the savanna and grassland ecosystems, the legume taxa continue to thrive and are most represented among the invasive species in nutrient poor ecosystems [11]. N-fixing bacteria and arbuscular mycorrhizal (AM) fungi symbiosis has been recognized as the driver of 
legume invasions as they can acquire $\mathrm{N}$ and $\mathrm{P}$, respectively $[12,13]$. The transfer of fixed carbon (C) from the host to the symbiont has a direct effect on the host plant, and, thus, it is important to quantify this process [14-16]. Generally, it is more cost-effective for plants to assimilate soil inorganic $\mathrm{N}$ than atmospheric $\mathrm{N}_{2}$ due to the $\mathrm{C}$ costs to symbionts [17]. Legumes can switch their $\mathrm{N}$ preferences due to nutritional stress, favoring soil $\mathrm{N}$ uptake to reserve energy [16-18]. Therefore, the availability and assimilation of soil inorganic $\mathrm{N}$ can reduce the cost of $\mathrm{N}_{2}$ fixation. In addition to symbiotic $\mathrm{N}$ fixation, non-symbiotic $\mathrm{N}$ fixation also plays an essential role in the grassland $\mathrm{N}$ economy [19].

Invasive legumes can efficiently exploit scarce nutrients and yield an aboveground biomass rich in $\mathrm{N}$ better than their neighboring native species. Consequently, $\mathrm{N}$ increases beyond levels at which the indigenous species are adapted to thrive [20,21], and so they may be displaced by invasive species due to their aggressive growth [22]. The $\mathrm{N}$ contributed by the biological nitrogen fixation (BNF) process from indigenous legumes is less than that produced by invasive legumes due to their slow growth rates and the absence of competition from natural enemies [23]. For example, the invasive legume from tropical Africa, Senna didymobotrya, can efficiently acquire more nutrients than native plants in South African poor soils [24]. This leads to the question of whether these invasive plants have traits or mechanisms that enhance their competitive ability for nutrient uptake and conversation [25]. It has been stated that invasive legumes nodulate readily using both native and non-native rhizobia species and are considered prolific $\mathrm{N}_{2}$-fixing species [26]. Rodríguez-Echeverría et al. [13] reported that Acacia longifolia was more efficient at forming a symbiotic association with bacteria and fixed more $\mathrm{N}$ than other co-occurring $\mathrm{N}_{2}$ fixing legumes, which was similar to that reported in the Cape fynbos [21]. Consequently, for the first time, this study investigates the plant-microbe symbiosis, plant nutrition, $\mathrm{C}$ costs and biomass accumulation in L. leucocephala grown in acidic grassland soils with varying $\mathrm{N}$ and P nutrient status. The proposed hypothesis was that L. leucocephala would establish plant-microbe symbiosis with multiple and more efficient $\mathrm{N}$-fixing bacteria and change its $\mathrm{N}$ source preference to reduce growth $\mathrm{C}$ costs in $\mathrm{P}$ deficient soils.

\section{Results}

\subsection{Soil Characteristics}

The average percentage $\mathrm{N}$ concentration was $11 \%$ lower in $\mathrm{N} 1$ and $\mathrm{N} 2+\mathrm{P}$ soils compared to the average percentage $\mathrm{N}$ concentration of $\mathrm{N} 2, \mathrm{~N} 3, \mathrm{~N} 1+\mathrm{P}$ and $\mathrm{N} 3+\mathrm{P}$ soils (Supplementary Table S1). The average percentage P concentration was 57\% higher in high $\mathrm{P}$ and N2 soils compared to the average percentage P concentration of N1 and N3 soils. Conversely, the average percentage $\mathrm{K}$ concentration was $51 \%$ higher in N1 and N3 soils compared to the average percentage $\mathrm{K}$ concentration of other experimental soils (high $\mathrm{P}$ and N2) (Supplementary Table S1). The average percentage exchangeable acidity was $74 \%$ higher in $\mathrm{N} 3$ and $\mathrm{N} 3+\mathrm{P}$ soils compared to the average percentage exchangeable acidity of $\mathrm{N} 1, \mathrm{~N} 1+\mathrm{P}$ and $\mathrm{N} 2+\mathrm{P}$ soils. All of the soils were acidic with a $\mathrm{pH}(\mathrm{KCl})$ below 5 except N2 $+\mathrm{P}$, which had the $\mathrm{pH}(\mathrm{KCl})$ of 5.01 . The $\mathrm{pH}(\mathrm{KCl})$ and $\mathrm{pH}\left(\mathrm{H}_{2} \mathrm{O}\right)$ in $\mathrm{N} 3$ and $\mathrm{N} 3+\mathrm{P}$ soils were $11 \%$ and $16 \%$ more acidic than other soils, respectively (Supplementary Table S1).

\subsection{Soil Bacteria and Plant Endophytic Bacterial Isolates Identification}

The molecular identification of $\mathrm{N}$-fixing and $\mathrm{N}$-cycling bacteria in the experimental soils used as growth substrate included Caulobacter rhizosphaerae, Sphingomonas sp. and Burkholderia contaminans, with accession no. and similarity (\%) detailed in Supplementary Table S2. Only the L. leucocephala plants grown in N2 + P soils were able to form a symbiotic association with the $\mathrm{N}$-fixing bacteria. The $16 \mathrm{~S}$ rRNA gene revealed that the symbionts were various intermediate and fast-growing strains from the Mesorhizobium and Rhizobium sp. in plants grown in this treatment (Supplementary Table S2) even though the Mesorhizobium and Rhizobium species were present in all soils. 


\subsection{Biomass and Mineral Contents}

L. leucocephala plants grown in $\mathrm{N}+\mathrm{P}$ soils had significantly higher total biomass than plants grown in other soils (Table 1). Leaf biomass was significantly higher in N1 and N $+\mathrm{P}$ soils (Table 1). Shoot and root biomass showed a similar trend of significantly higher values in the $+\mathrm{P}$ treatments than in the $\mathrm{N}$ only treatments (Table 1). The root-shoot ratio of the plants grown in N3 + P soils was significantly higher compared to the N2 and N3 soils (Table 1). The P concentration was significantly higher in L. leucocephala grown in the N1 and in the $+\mathrm{P}$ soils than in the $\mathrm{N} 2$ and $\mathrm{N} 3$ soils. Inversely, the plant $\mathrm{N}$ concentration was significantly higher in the $\mathrm{N} 2$ and $\mathrm{N} 3$ soils than in the $\mathrm{N} 1$ and $\mathrm{N}+\mathrm{P}$ soils (Table 1).

Table 1. Biomass and mineral contents of 180-day-old L. leucocephala plants grown in Veld Fertilizer Trial soils from Ukulinga Experimental Farm, South Africa. Values represent the mean $\pm \mathrm{SE}$, based on $n=5$. Significant differences among treatments are denoted by different superscript letters $(p<0.05)$.

\begin{tabular}{|c|c|c|c|c|c|c|}
\hline \multirow{2}{*}{ Parameter } & \multicolumn{6}{|c|}{ Treatment Trials } \\
\hline & N1 & N2 & N3 & $\mathrm{N} 1+\mathbf{P}$ & $\mathrm{N} 2+\mathrm{P}$ & $\mathrm{N} 3+\mathrm{P}$ \\
\hline \multicolumn{7}{|l|}{ Biomass (g DW) } \\
\hline Total plant & $1.285 \pm 0.090^{b}$ & $1.154 \pm 0.465^{\mathrm{ab}}$ & $0.589 \pm 0.042^{\mathrm{a}}$ & $2.366 \pm 0.236^{c}$ & $2.036 \pm 0.236^{b c}$ & $2.891 \pm 0.503^{c}$ \\
\hline Leaves & $0.403 \pm 0.034^{b}$ & $0.373 \pm 0.126^{a}$ & $0.176 \pm 0.008^{a}$ & $0.737 \pm 0.106^{b}$ & $0.516 \pm 0.087^{b}$ & $0.643 \pm 0.098^{b}$ \\
\hline Shoot & $0.305 \pm 0.026^{b}$ & $0.272 \pm 0.086^{\mathrm{ab}}$ & $0.179 \pm 0.026^{\mathrm{a}}$ & $0.579 \pm 0.056^{c}$ & $0.555 \pm 0.075^{\mathrm{c}}$ & $0.761 \pm 0.099^{c}$ \\
\hline Roots & $0.576 \pm 0.040^{b c}$ & $0.509 \pm 0.257^{a b}$ & $0.233 \pm 0.020^{\mathrm{a}}$ & $1.049 \pm 0.122^{\mathrm{d}}$ & $0.964 \pm 0.098^{\mathrm{cd}}$ & $1.487 \pm 0.345^{\mathrm{d}}$ \\
\hline Root-shoot ratio & $0.819 \pm 0.039^{a b}$ & $0.667 \pm 0.100^{\mathrm{a}}$ & $0.659 \pm 0.039^{a}$ & $0.804 \pm 0.063^{a b}$ & $0.924 \pm 0.054^{\mathrm{ab}}$ & $1.049 \pm 0.138^{b}$ \\
\hline \multicolumn{7}{|l|}{ Mineral contents } \\
\hline $\begin{array}{c}\text { Total plant N } \\
\left(\mathrm{mmol} \mathrm{Ng}^{-1} \mathrm{DW}\right)\end{array}$ & $1.080 \pm 0.051^{\mathrm{a}}$ & $1.596 \pm 0.168^{b}$ & $1.992 \pm 0.096^{c}$ & $0.948 \pm 0.027^{a}$ & $0.902 \pm 0.055^{\mathrm{a}}$ & $0.938 \pm 0.034^{a}$ \\
\hline $\begin{array}{l}\text { Standard corrected } \\
{ }^{15} \mathrm{~N} /{ }^{14} \mathrm{~N}\end{array}$ & $2.550 \pm 0.151^{a b}$ & $3.262 \pm 0.177^{\mathrm{b}}$ & $2.319 \pm 0.230^{a b}$ & $1.099 \pm 0.169^{a}$ & $1.430 \pm 0.200^{\mathrm{a}}$ & $1.101 \pm 0.322^{a}$ \\
\hline $\begin{array}{c}\text { Total plant P } \\
\left(\mu \mathrm{mol} \mathrm{P} \mathrm{g}{ }^{-1} \mathrm{DW}\right)\end{array}$ & $60.92 \pm 5.615^{b}$ & $21.37 \pm 2.739^{a}$ & $15.63 \pm 0.912^{\mathrm{a}}$ & $76.60 \pm 2.896^{b}$ & $59.22 \pm 2.372^{b}$ & $82.99 \pm 12.99^{b}$ \\
\hline
\end{tabular}

\subsection{Growth Rates and Carbon Construction Costs}

L. leucocephala plants grown in the $\mathrm{N} 1$ and $\mathrm{N}+\mathrm{P}$ soils attained significantly higher growth rates compared to L. leucocephala grown in N3 soils (Figure 1A). A similar trend was observed in the relative growth rate, which was also higher in these treatments (Figure 1B). In relation to the carbon construction costs, the $\mathrm{N} 3$ and $\mathrm{N} 2+\mathrm{P}$ soils presented the highest values when compared to the $\mathrm{N} 1+\mathrm{P}$ and N3 + P soils (Figure 1C).

\section{5. $N$ and $P$ Use Efficiencies}

Plants grown in N2 and N3 soils showed increased specific $\mathrm{N}$ assimilation rate (SNAR), while plants grown in other soils had lower values (Figure 2A). The specific N utilization rate (SNUR) was much greater in the $\mathrm{N}+\mathrm{P}$ soils than in the other soils (Figure 2C). The specific $\mathrm{P}$ assimilation rate (SPAR) was significantly greater in L. leucocephala plants grown in the $\mathrm{N} 1$ and N+P soils than in plants of other soils (Figure 2B), while the specific $\mathrm{P}$ utilization rate (SPUR) was significantly higher in L. leucocephala plants grown in $\mathrm{N}+\mathrm{P}$ soils than plants in other soils (Figure 2D). 

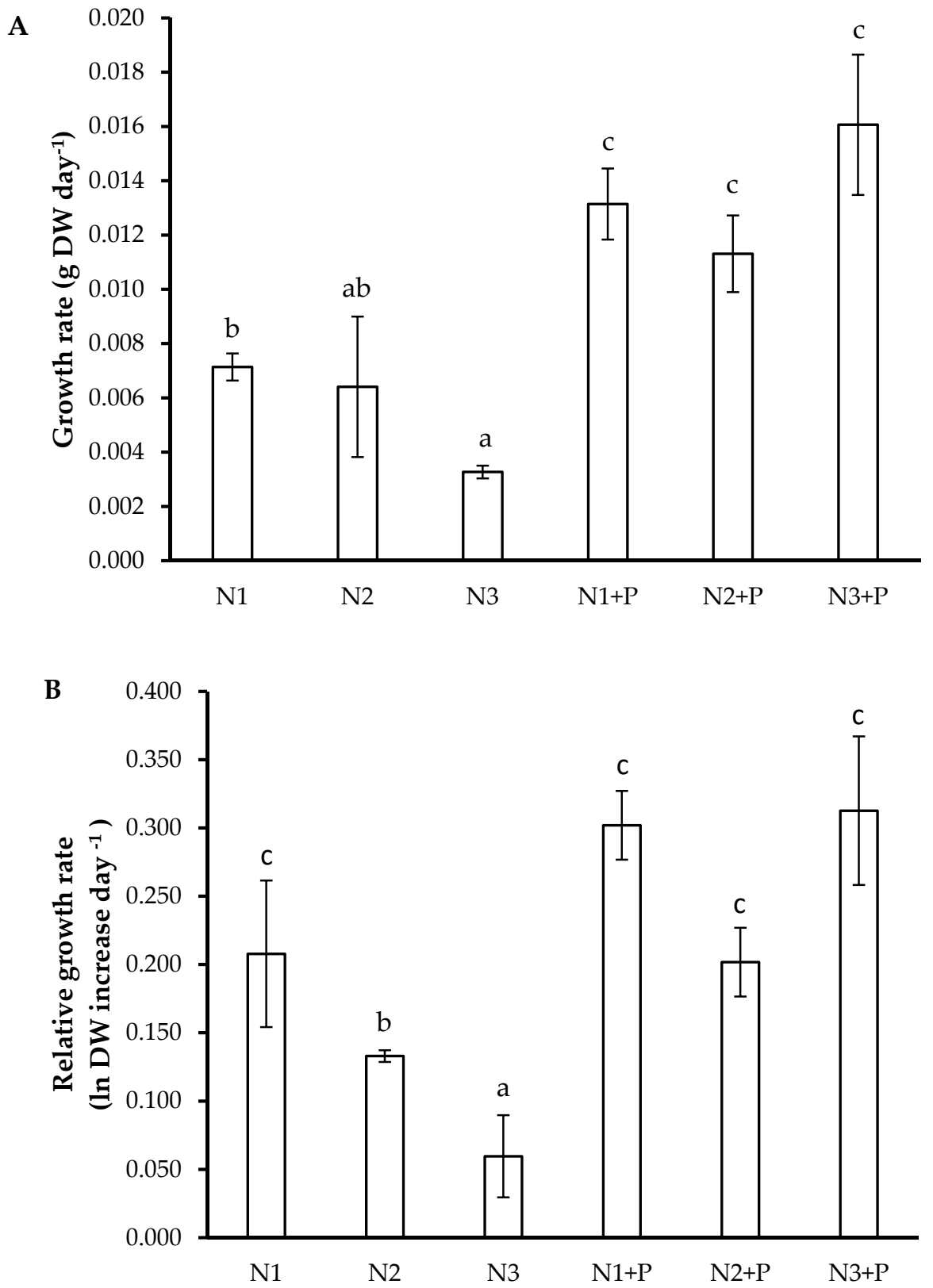

Figure 1. Cont. 


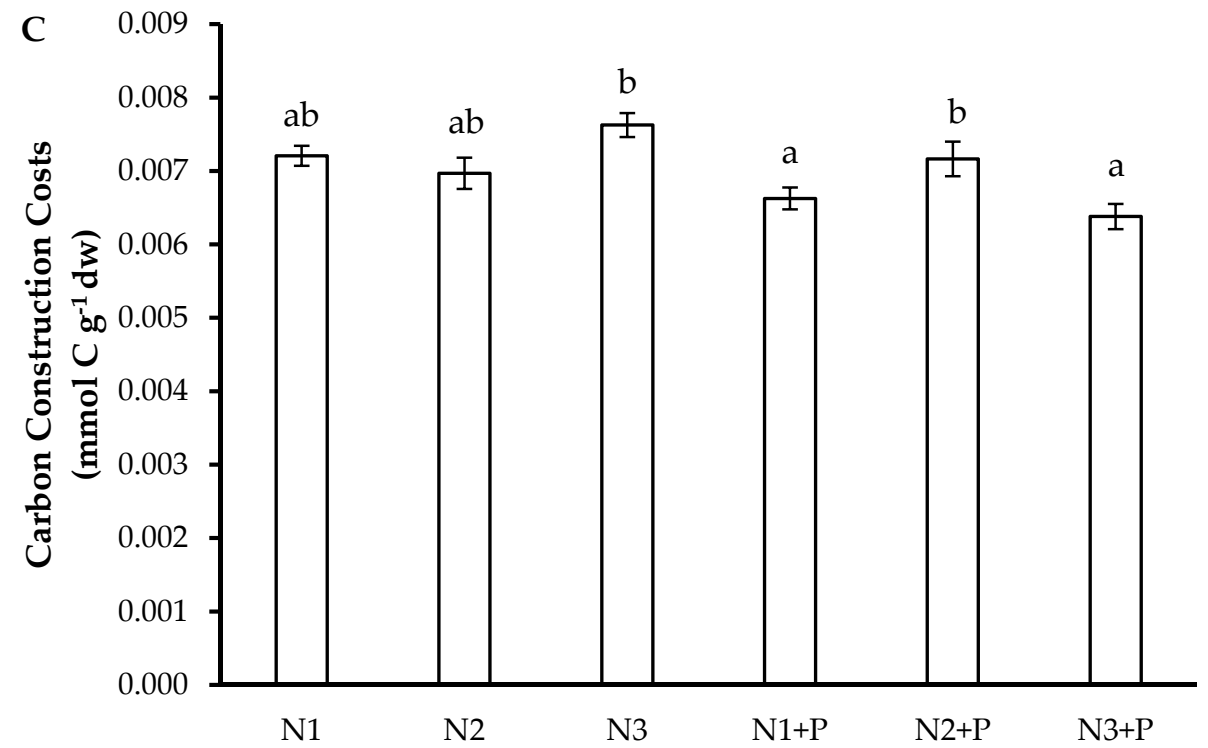

Figure 1. (A) Growth rate (g DW day $\left.{ }^{-1}\right)$; (B) Relative growth rate (ln DW increase day ${ }^{-1}$ ); (C) Carbon construction costs (mmol C g ${ }^{-1} \mathrm{DW}$ ) of 180-day-old L. leucocephala saplings grown in Veld Fertilizer Trial soils from Ukulinga Experimental Farm, South Africa. The values represent the mean \pm SE, based on $n=5$. Significant differences among treatments $(p<0.05)$ are denoted by different superscript letters.

A

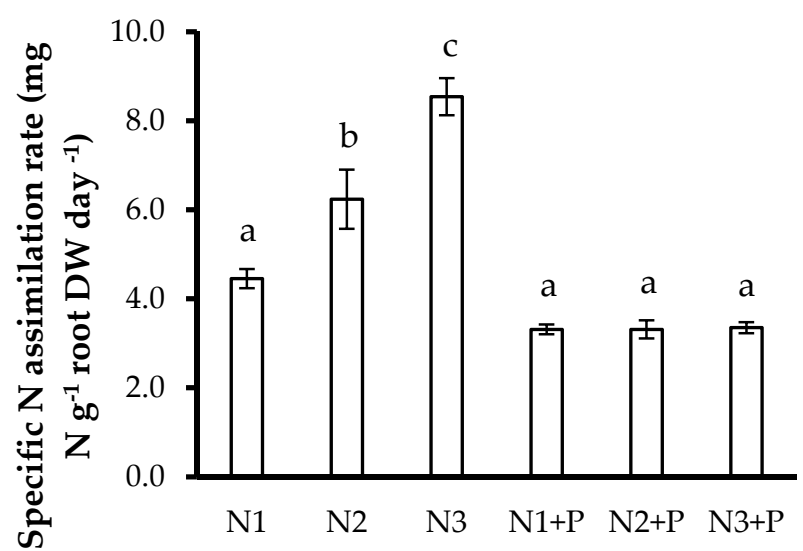

B

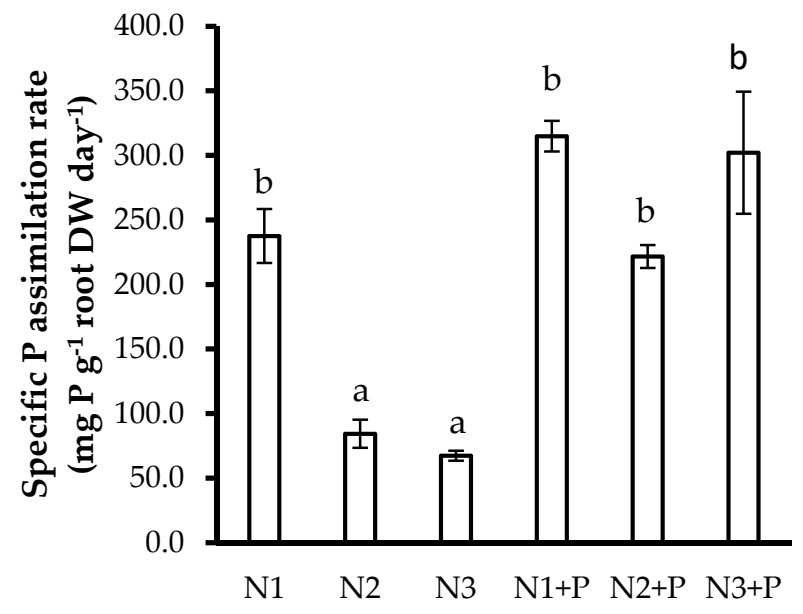

Figure 2. Cont. 
C

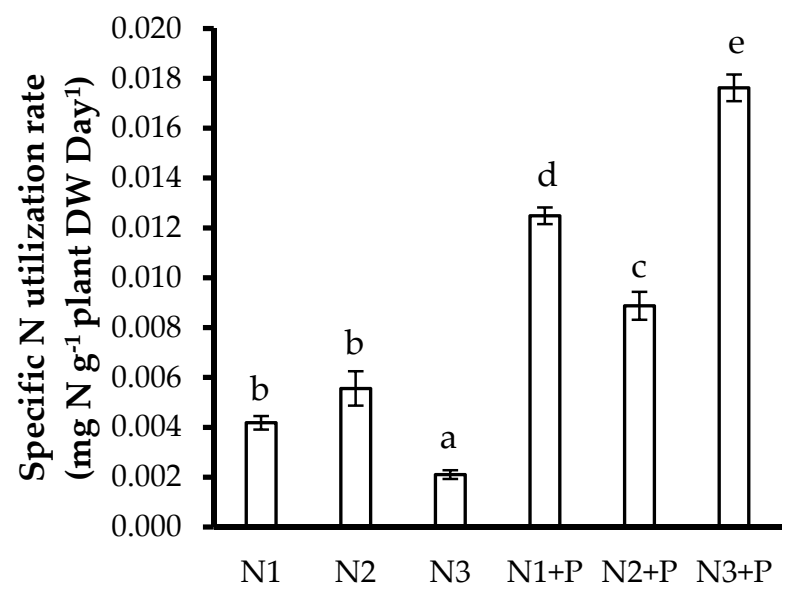

D

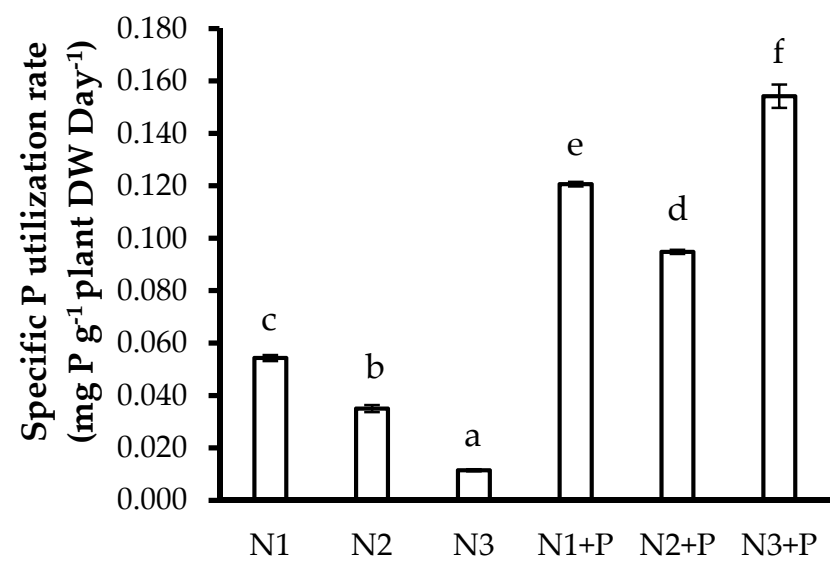

Figure 2. (A) Specific $\mathrm{N}$ assimilation rate $\left(\mathrm{mg} \mathrm{N} \mathrm{g}^{-1}\right.$ root $\mathrm{DW}$ day $\left.{ }^{-1}\right)$; (B) Specific $\mathrm{P}$ assimilation rate ( $\mathrm{mg} \mathrm{P} \mathrm{g}^{-1}$ root DW

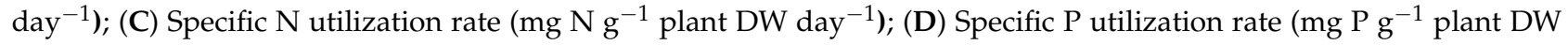
day $^{-1}$ ) of 180-day-old L. leucocephala saplings grown in Veld Fertilizer Trial soils from Ukulinga Experimental Farm, South Africa. Values represent the means $\pm \mathrm{SE}$, based on $n=5$. Significant differences among treatments $(p<0.05)$ are denoted by different superscript letters.

\section{6. $N$ Preference}

Plants grown in the $\mathrm{N}+\mathrm{P}$ soils relied more on NDFA, whereas the low $\mathrm{P}$ soil grown plants (i.e., the $\mathrm{N}$ only treatments) relied more on NDFS (Figure 3).

\section{A}

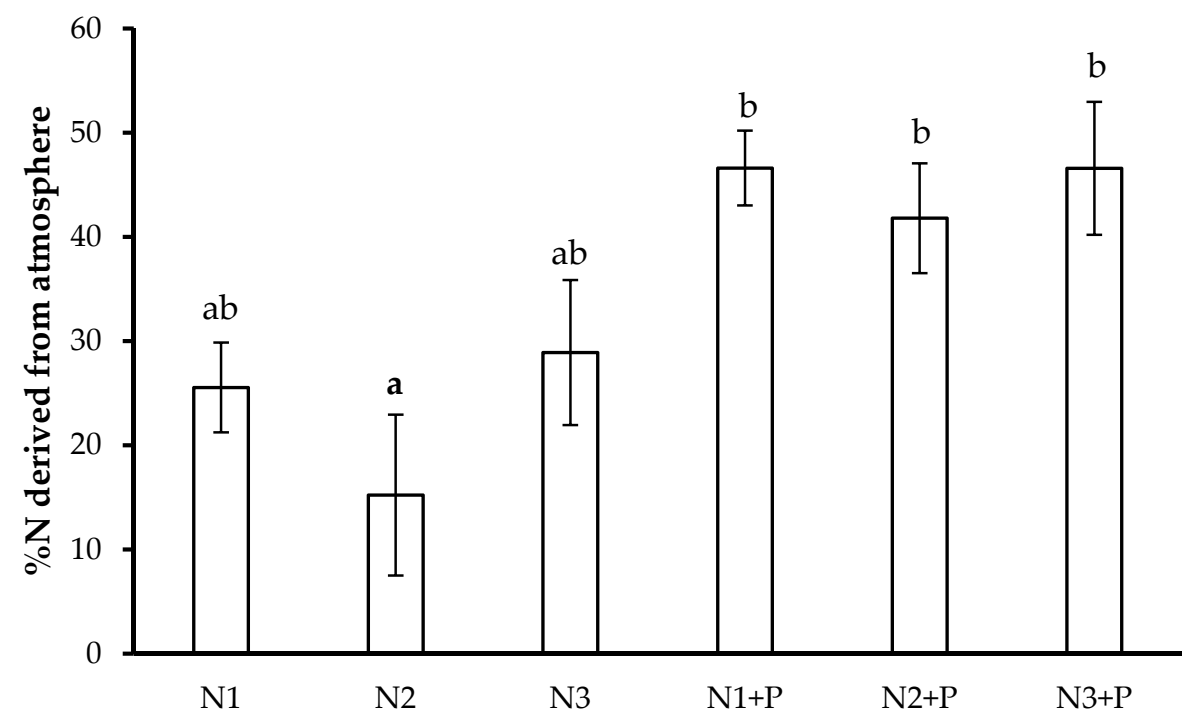

Figure 3. Cont. 


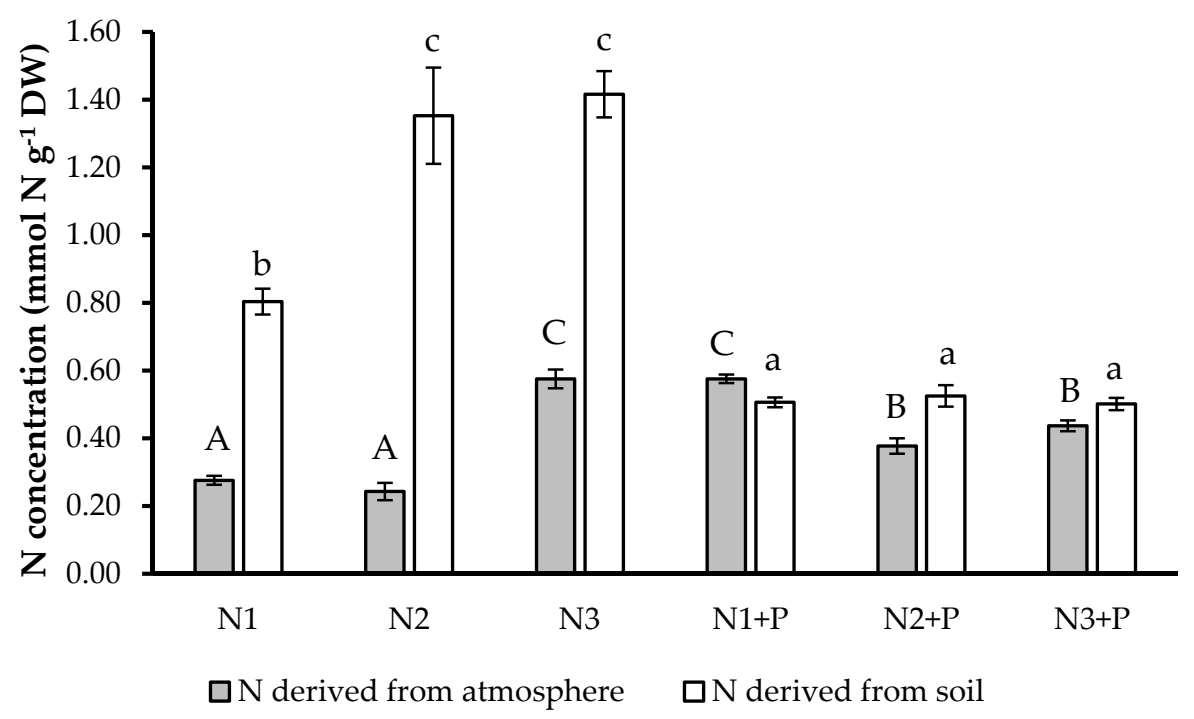

Figure 3. $\mathrm{N}$ preferences (A) Percentage $\mathrm{N}$ derived from the atmosphere, (B) Plant $\mathrm{N}$ concentration derived from atmosphere and Plant $\mathrm{N}$ concentration derived from soil (mmol $\left.\mathrm{N} \mathrm{g}^{-1} \mathrm{DW}\right)$ ) of 180-day-old L. leucocephala saplings grown in Veld Fertilizer Trial soils from Ukulinga Experimental Farm, South Africa. Values represent the means \pm SE, based on $n=5$. Significant differences among treatments $(p<0.05)$ are denoted by different superscript letters.

\section{Discussion}

Leucaena leucocephala was able to grow in acidic KZN grassland soils with variable $\mathrm{N}$ and $\mathrm{P}$ by regulating their growth, nutrient assimilation and utilization rates. Moreover, the L. leucocephala plants grown in soils with moderate $\mathrm{N}$ and high $\mathrm{P}(\mathrm{N} 2+\mathrm{P})$ concentrations were the only plants that established a symbiosis with the N-fixing bacteria. The $16 \mathrm{~S} r$ RNA gene revealed that several species from the Mesorhizobium and Rhizobium genus inhabited the nodules of L. leucocephala grown in $\mathrm{N} 2+\mathrm{P}$ soils. Non-nodulations in the L. leucocephala plants grown in the $\mathrm{P}$ deficient, low $\mathrm{N}$ and high $\mathrm{N}$ with $\mathrm{P}$ soils could be attributed to the low $\mathrm{pH}$ levels $(\mathrm{pH}(\mathrm{KCl}) 4.12-4.67)$ observed in these soils compared to $\mathrm{pH}(\mathrm{KCl}) 5.01$ in $\mathrm{N} 2+\mathrm{P}$ soils. Extreme low pH levels have been reported to reduce approximately $90 \%$ nodulation in various species such as cowpea, pea, Lucerne and soybean [27], affecting both indeterminate and determinate nodules. For example, acidity disrupts the signaling mechanisms between the Rhizobium and the plant roots, as explained in detail by $[27,28]$.

In addition, nodule formation and plant growth in L. leucocephala plants grown in N3 soils could have been negatively affected by increased ammonium $\left(\mathrm{NH}_{4}{ }^{+}\right)$in the soil [29]. $\mathrm{NH}_{4}{ }^{+}$is a paradoxical nutrient: it is beneficial due to its readily oxidative state for plant assimilation but can cause toxicity symptoms when available in large amounts. Therefore, increased soil $\mathrm{N}$ fertilization, and soil acidity may have reduced the total biomass of N3 grown L. leucocephala. This is highlighted by the increase in specific $\mathrm{N}$ assimilation rates, decreased specific $\mathrm{N}$ utilization rates and plant growth rates in N3 soil grown plants. Limited soil P may have also contributed to the decreased biomass as P is the second most essential nutrient required for plant growth and development [30]. In P-limited and acidic soil conditions, some legumes often prefer NDFS to NDFA as it is assumed that biological $\mathrm{N}$ fixation (BNF) requires significantly high amounts of energy (ATP) to fix one molecule of $\mathrm{N}$ compared to the energy required for the uptake and reduction in $\mathrm{NO}_{3}[31,32]$. This could explain the observed $\mathrm{N}$ derived from soil results across all soils. The percentage NDFA was high in nodulated and non-nodulated L. leucocephala plants grown in P fertilized soil, showing the significance of $\mathrm{P}$ as an energy driver in this process [31,32]. In addition to symbiotic $\mathrm{N}$ fixation, invasive legumes also depend on non-symbiotic $\mathrm{N}$ fixation by bacteria species [33] as they supply $\mathrm{N}$ in both organic and inorganic form [34]. Therefore, 
non-nodulation and NDFA in the L. leucocephala plants suggest an association with nonnodulating endophytic or associative rhizosphere $\mathrm{N}$-fixing bacteria species. The presence of bacteria from the Burkholderia and Caulobacter genus in the soil has been reported to improve plant and soil health by supplying urea-N from BNF [35]. Sphingomonas sp. has been isolated in barley, millet and wheat and reported to fix atmospheric $\mathrm{N}$, and has been classified as plant growth-promoting bacteria [32]. $\mathrm{N}$-fixing and $\mathrm{N}$-cycling bacteria (Caulobacter rhizosphaerae, Burkholderia contaminans and Sphingomonas sp.) were identified in the experimental soils used as growth substrate. Even with the increased NDFA in high P soils, L. leucocephala plants utilized $\mathrm{N}$ derived from the atmosphere and $\mathrm{N}$ from the soil (NDFS).

$\mathrm{N}$ and $\mathrm{P}$ often limited plant growth in grassland ecosystems as plants often increase growth when both $\mathrm{N}$ and $\mathrm{P}$ are added in soils [36]. This was also observed in the current study as the L. leucocephala plants grown in $\mathrm{N}+\mathrm{P}$ soils had higher total biomass than the L. leucocephala plants grown in -P soils. Surprisingly, L. leucocephala grown in N1 soils accumulated more total biomass and increased growth rate compared to plants grown in $\mathrm{N} 2$ and $\mathrm{N} 3$ soils regardless of the soils having a significantly low concentration of $\mathrm{N}$ and $\mathrm{P}$. This could be attributed to the various adaptations displayed by plants during P deficiency. These adaptations include investing more resources on below ground biomass to increase the root surface area for nutrient absorption [37]. This might have been the case in N1 grown plants as the root biomass was significantly greater. Changes in root architecture due to nutrient deficiency are reported to increase $P$ acquisition through increased mining of limiting nutrients in the rhizosphere [37]. This concurs with our findings as N1 grown L. leucocephala had an increased specific phosphorus absorption rate (SPAR) and specific phosphorus utilization rate (SPUR) coupled with an increased P content. The study conducted was important in providing a general understanding of L. leucocephala response to nutrient variability associated with acidity in grassland ecosystem soils. Further research on the interactions of L. leucocephala with native legume plants in these ecosystems is pertinent to generate more information to link to the physiological adaptations of L. leucocephala.

\section{Materials and Methods}

\subsection{Study Site}

Soil samples were collected from the Veld Fertilizer Trial (VFT) at Ukulinga $\left(29^{\circ} 24^{\prime}\right.$ E, $30^{\circ} 24^{\prime} \mathrm{S}$; altitude $847 \mathrm{~m}$ above sea level), a research farm of the University of KZN in Pietermaritzburg, South Africa. The mean precipitation and temperature of the area is approximately $838 \mathrm{~mm}$ and $18{ }^{\circ} \mathrm{C}$, respectively [38]. The vegetation at Ukulinga is described as KwaZulu-Natal Hinterland Thornveld [39], which is an open savanna dominated by tall C4 grasses such as Themeda triandra, Hyparrhenia hirta and Heteropogon contortus while the sparse tree layer is dominated by Vachellia sieberiana and V. nilotica. Soils are deep $(600-1000 \mathrm{~mm})$ dolerites and shales derived from Karoo sediments of the Westleigh form [39].

\subsection{Experimental Design}

The VFT was initiated in 1951 through the addition of fertilizer (nitrogen (N), phosphorus $(\mathrm{P})$ ) and lime (L) to improve grassland productivity. There were initially 96 plots from 1951-2019 and each plot was $9.0 \mathrm{~m} \times 2.7 \mathrm{~m}^{2}$ in size with a $1 \mathrm{~m}$ spacing between plots. The VFT experiment was replicated in three blocks, each block containing 32 plots, resulting in a $4 \times 23$ treatment structure laid out in a complete randomized design. For the purposes of this study, we used treatment plots fertilized with $\mathrm{N}$ in the form of limestone ammonium nitrate (LAN) and $\mathrm{P}$ in the form of superphosphate. Three levels of $28 \% \mathrm{LAN}(\mathrm{N} 1=210 \mathrm{~kg} / \mathrm{ha} /$ season; $\mathrm{N} 2=421 \mathrm{~kg} / \mathrm{ha} /$ season and N3 $=632 \mathrm{~kg} / \mathrm{ha} /$ season $)$ fertilizer. In addition, the three $\mathrm{N}$ levels were also applied in combination with one level of $11.3 \%$ superphosphate $(336 \mathrm{~kg} / \mathrm{ha} /$ season $)(\mathrm{N} 1+\mathrm{P}, \mathrm{N} 2+\mathrm{P}$ and $\mathrm{N} 3+\mathrm{P})$. This completely randomized block design experiment for this study adds up to six treatments. 


\subsection{Soil Characteristics Analysis and Bacterial Identification}

For each of the six treatments, five soil samples were obtained from each plot in the three blocks to a depth of $30 \mathrm{~cm}$. Thereafter, the soils for each treatment were pooled for uniformity. Five subsamples of $50 \mathrm{~g}$ soil from each treatment were sent for analysis, which included nutrients such as $\mathrm{P}, \mathrm{N}, \mathrm{K}$ and other soil properties such as $\mathrm{pH}$, acidity exchange and total cation at the KZN Department of Agriculture and Rural Development Analytical Services Unit at Cedara, South Africa. In addition to the soil characteristics, soil moisture factor was also accounted for by drying five soil samples from each treatment in an oven at $105^{\circ} \mathrm{C}$ until a constant weight was achieved, as detailed by [40]. An additional 5 soil samples (250-300 g) from each treatment were used for microbial identification, where the bacterial template DNA was extracted using a modified boiling procedure, by boiling $300 \mu \mathrm{L}$ of bacterial culture in 10\% TSA suspended in Milli-Q water in a safe-lock Eppendorf tube for $10 \mathrm{~min}$, cooled on ice and centrifuged as described by [41]. The bacterial DNA amplification using the $16 \mathrm{~S}$ rRNA gene, sequencing and identification was performed as detailed in [42].

\subsection{Seed Collection, Germination and Growth Conditions}

Seeds of L. leucocephala were collected from randomly located trees at Roosfontein Nature Reserve, Durban, South Africa. The experiment was conducted under ambient conditions in a greenhouse at the University of KZN botanical garden at Pietermaritzburg, South Africa. The conditions in the greenhouse were: day-time temperatures of 12 to $14{ }^{\circ} \mathrm{C}$ and night-time temperatures of 30 to $35{ }^{\circ} \mathrm{C}$ with humidity from $70 \%$ to $80 \%$ and irradiance $\sim 35 \%$ of full sunlight (i.e., $415.6 \mu \mathrm{mol} \mathrm{m}^{-2} \mathrm{~s}^{-1}$ ). Prior to germination, the seeds were soaked in $15 \%$ sodium hypochlorite for $20 \mathrm{~min}$. Thereafter, they were rinsed five times in distilled water and then placed in petri dishes layered with Whatman's filter paper for germination. The seeds were watered every day until seedling emergence (10 days). Thereafter, in $15 \mathrm{~cm}$ diameter pots, seedlings were planted at a depth of $\sim 2 \mathrm{~cm}$. Each soil treatment had 20 replicates. Plants were irrigated every 2 days in the afternoon depending on the climatic conditions.

\subsection{Plant Harvesting and Nutrient Analysis}

The initial harvest of five plants from each treatment for the initial values required in the growth calculations took place after 30 days and final harvests of 10 plants from each treatment took place 180 days after seedling emergence. At each harvest time, plants were rinsed with distilled water then separated into leaves, stems, roots and nodules, and, thereafter, oven dried at $65{ }^{\circ} \mathrm{C}$ for 4 days before weighing and grinding to a powder. The ground plant material was stored in $2 \mathrm{~mL}$ Eppendorf tubes and was sent for $\mathrm{C}$ and isotope $\mathrm{N}$ analysis at the Archaeometry Department, University of Cape Town, and for $\mathrm{P}$ analysis at the Central Analytical Facilities at Stellenbosch University, both in South Africa. Five remaining plants from the $\mathrm{N} 2+\mathrm{P}$ treatment were nodulated, root nodules were harvested for bacterial extraction. Root nodules were rinsed with distilled water, then sterilized in ethanol $70 \%(v / v)$ for $30 \mathrm{~s}$ and with 3.5\% $(v / v)$ sodium hypochlorite solution for $3 \mathrm{~min}$, and, thereafter, rinsed 10X with distilled water then stored in airtight vials containing silica gel and cotton wool. The vials were then stored at $4{ }^{\circ} \mathrm{C}$ for bacterial extraction, culturing in yeast mannitol agar (YMA) and sequencing.

\subsection{Bacterial Extraction and Identification}

Prior to bacterial extraction, the nodules were transferred into $2 \mathrm{~mL}$ Eppendorf tubes containing distilled water and left overnight to absorb water at $4{ }^{\circ} \mathrm{C}$. The nodules were again sterilized in ethanol $70 \%(v / v)$ for $30 \mathrm{~s}$ and with $3.5 \%(v / v)$ sodium hypochlorite solution for $3 \mathrm{~min}$. Thereafter, nodules were rinsed 10X with distilled water. The second sterilization was to remove any contaminants that might have been introduced during storage. The nodule samples were then crushed in $15 \%$ glycerol solution. The turbid nodule solution in $15 \%$ glycerol was streaked in plates containing yeast mannitol agar 
(YMA) containing $0.5 \mathrm{~g} / \mathrm{L}$ yeast extract (Glentham Life Sciences Ltd., Corsham, UK), $10 \mathrm{~g} / \mathrm{L}$ mannitol (Merck KGaA, Darmstadt, Germany), $0.5 \mathrm{~g} / \mathrm{L}$ di-potassium hydrogen orthophosphate $\left(\mathrm{K}_{2} \mathrm{HPO}_{4}\right.$, Merck KGaA, Darmstadt, Germany), $0.2 \mathrm{~g} / \mathrm{L}$ magnesium sulfate heptahydrate $\left(\mathrm{MgSO}_{4} .7 \mathrm{H}_{2} \mathrm{O}\right.$, Merck KGaA, Darmstadt, Germany), $0.1 \mathrm{~g} / \mathrm{L}$ sodium chloride (NaCl, Merck KGaA, Darmstadt, Germany), $15 \mathrm{~g} / \mathrm{L}$ bacteriological agar (Merck KGaA, Darmstadt, Germany) and incubated at $28^{\circ} \mathrm{C}$. The bacteria were re-streaked into fresh plates until pure colonies/cultures were obtained.

The pure bacterial colonies/cultures randomly selected based on phenotypes were amplified using a portion of 16-S rRNA gene, 27F (5'-AGAGTTTGATCCTGGCTCAG-3') and 1492R (5'-GGTTACCTTGTTACGACTT-3'). Bacterial DNA amplification was performed following the protocol: initial denaturation for $5 \mathrm{~min}$ at $94{ }^{\circ} \mathrm{C}, 30$ cycles of denaturation $30 \mathrm{~s}$ at $94^{\circ} \mathrm{C}$, annealing at $55^{\circ} \mathrm{C}$ and elongation for $2 \mathrm{~min}$ at $72{ }^{\circ} \mathrm{C}$, followed by a final elongation step of $10 \mathrm{~min}$ at $72{ }^{\circ} \mathrm{C}$ using a Bio-Rad Mini Opticon Thermal cycler (BioRad Laboratories Ltd., Rosebank, Gauteng, South Africa). In total, $25 \mu \mathrm{L}$ PCR reactions contained $11 \mu \mathrm{L}$ sterile distilled water, $12.5 \mu \mathrm{L}$ TAKARA-EmeraldAmp GT PCR Master Mix (Separations, Randburg, Gauteng, South Africa), 0.25 $\mu \mathrm{L}$ 27F primer, $0.25 \mu \mathrm{L} 1492 \mathrm{R}$ primer and $1 \mu \mathrm{L}$ of DNA colony. The results were viewed in $1 \%(m / v)$ agarose gel electrophoresis using TAE buffer and run at $100 \mathrm{~V}$ for $20 \mathrm{~min}$. Thereafter, amplified products were sent for sequencing at the Central Analytical Facilities. The resulting sequences were edited and subjected BLASTN (National Center for Biotechnology Information, NCBI, https:/ / www.ncbi.nlm.nih.gov / genbank/ accessed on 16 June 2020) to compare them to all of the other bacterial 16S rRNA sequences already in the database.

\subsection{Growth Calculations}

\subsubsection{Calculation of the Specific N/P Absorption and Utilization Rates}

Specific $\mathrm{N}$ and $\mathrm{P}$ absorption rate (SNAR) values were calculated according to [43] by calculating the total $\mathrm{N}$ and $\mathrm{P}$ absorbed/assimilated by the plant roots $\left(\mathrm{mg} \mathrm{N} / \mathrm{P} \mathrm{g}^{-1}\right.$ root DW day $^{-1}$ )

$$
\begin{aligned}
\operatorname{SNAR} & =\left(\mathrm{N}_{2}-\mathrm{N}_{1} / \mathrm{t}_{2}-\mathrm{t}_{1}\right) *\left[\left(\log _{\mathrm{e}} \mathrm{R}_{2}-\log _{\mathrm{e}} \mathrm{R}_{1}\right) /\left(\mathrm{R}_{2}-\mathrm{R}_{1}\right)\right] \\
\operatorname{SPAR} & =\left(\mathrm{P}_{2}-\mathrm{P}_{1} / \mathrm{t}_{2}-\mathrm{t}_{1}\right) *\left[\left(\log _{\mathrm{e}} \mathrm{R}_{2}-\log _{\mathrm{e}} \mathrm{R}_{1}\right) /\left(\mathrm{R}_{2}-\mathrm{R}_{1}\right)\right]
\end{aligned}
$$

where $\mathrm{N}$ and $\mathrm{P}$ denote the total nitrogen and phosphorus content in the plant, respectively, $t_{2}-t_{1}$ is the difference in time between the final and initial harvest and $R_{2}$ and $R_{1}$ are the final and initial root dry weight, respectively, as described in [43].

Specific $\mathrm{N}$ and P utilization rate (SNUR) values were calculated according to [43] by calculating the dry weight acquired by the plant during nitrogen uptake $\left(\mathrm{g} D W \cdot \mathrm{mg}^{-1}\right.$ $\mathrm{N} / \mathrm{P} \cdot$ day $^{-1}$ )

$$
\begin{gathered}
\text { SNUR }=\left(\mathrm{W}_{2}-\mathrm{W}_{1} / \mathrm{t}_{2}-\mathrm{t}_{1}\right) *\left[\left(\log _{\mathrm{e}} \mathrm{N}_{2}-\log _{\mathrm{e}} \mathrm{N}_{1}\right) /\left(\mathrm{N}_{2}-\mathrm{N}_{1}\right)\right] \\
\text { SPUR }=\left(\mathrm{W}_{2}-\mathrm{W}_{1} / \mathrm{t}_{2}-\mathrm{t}_{1}\right) *\left[\left(\log _{\mathrm{e}} \mathrm{P}_{2}-\log _{\mathrm{e}} \mathrm{P}_{1}\right) /\left(\mathrm{P}_{2}-\mathrm{P}_{1}\right)\right]
\end{gathered}
$$

where $\mathrm{W}$ is the plant's dry weight [43] and the other parameters are as defined in the SNAR equation.

Relative growth rate was calculated according to [44] by calculating the total plant dry weight increase in a time interval in relation to the initial weight or dry matter (ln DW increase $\cdot$ day $^{-1}$ ).

$$
\mathrm{RGR}=\left[\left(\ln \mathrm{W}_{2}-\ln \mathrm{W}_{1}\right) /\left(\mathrm{t}_{2}-\mathrm{t}_{1}\right)\right]
$$

where $\mathrm{W}$ denotes the dry weights (DW) of the final and initial harvest and $t_{2}-t_{1}$ is the difference in time between the harvests. 


\subsubsection{Carbon Construction Costs}

Carbon construction costs $\left(\mathrm{C}_{\mathrm{W}}\right)\left(\mathrm{mmol} \mathrm{C} \mathrm{g}{ }^{-1}\right.$ dry weight $\left.(\mathrm{DW})\right)$ were calculated from Mortimer et al. [45] as derived from Peng et al. [46] as follows

$$
\mathrm{C}_{\mathrm{w}}=(\mathrm{C}+\mathrm{kN} / 14 * 180 / 24)(1 / 0.89)(6000 / 180)
$$

$\mathrm{C}_{\mathrm{W}}$ denotes tissue total carbon construction cost, $\mathrm{C}$ is the total concentration of carbon $\left(\mathrm{mmol} \mathrm{C} \mathrm{g}{ }^{-1}\right), \mathrm{k}$ is the reduction state of $\mathrm{N}$ substrate (for $\mathrm{NH}_{3}=-3$ ) and $\mathrm{N}$ is the total organic nitrogen content of the tissue $\left(\mathrm{g} \mathrm{DW}^{-1}\right)$, as described by [47]. The value 14 is the atomic mass of N, 180 is a conversion factor from moles to grams of glucose, the amount of electrons in a glucose molecule that are available is 24, 0.89 is an estimate of growth efficiency [47] and the fraction $6000 / 180$ is a constant conversion factor from $\mathrm{g}^{-1}$ dry weight to mmol $\mathrm{C} \mathrm{g}^{-1} \mathrm{DW}$ for glucose.

\subsubsection{Determination and Calculation of $\mathrm{N}$ Derived from the Atmosphere}

Isotopic $\mathrm{N}$ was analysed following the protocols at the Archaeometry Department, University of Cape Town where samples were combusted in a Fisons NA 1500 (Series 2) $\mathrm{CHN}$ analyser (Fisons Instruments $\mathrm{SpA}$, Milan, Italy). Isotope $\mathrm{N}$ values for the $\mathrm{N}$ gas released were determined using the Finnigan Matt 252 mass spectrometer (Finnigan MAT $\mathrm{GmbH}$, Bremen, Germany), connected to a CHN analyser by a Finnigan MAT Conflo control unit. A total of five standards were used to correct the samples for machine drift. The $\mathrm{N}$ isotopic ratio was calculated as $\delta=1000\left(R_{\text {sample }} / R_{\text {standard }}\right)$, where $R$ is the molar ratio of the heavier to the lighter isotope of the samples and standards.

$$
\% \mathrm{NDFA}=100\left(\left(\delta^{15} \mathrm{~N} \text { reference plant }-\delta^{15} \mathrm{~N} \text { legume }\right) /\left(\delta^{15} \mathrm{~N} \text { reference plant }-\beta\right)\right)
$$

where NDFA is the $\mathrm{N}$ derived from the atmosphere. The $\beta$ value represents the $\delta^{15} \mathrm{~N}$ natural abundance of the $\mathrm{N}$ derived from biological $\mathrm{N}_{2}$ fixation, which for L. leucocephala plants grown in $\mathrm{N}$ free culture was determined to be $-2.60 \%$.

\section{Statistical Analysis}

The effects of $\mathrm{N}$ and $\mathrm{P}$ concentration variability in the VFT on plant biomass, plant mineral nutrition and growth kinetics were examined by one-way analysis of variance (ANOVA), followed by Tukey's HSD post hoc tests. $(p<0.05)$., Where the assumptions of normality were not satisfied, a Kruskal-Wallis test was performed. Statistical analysis was performed using SPSS Statistics for windows v. 26 (IBM Corp., Armonk, NY, USA).

\section{Conclusions}

Leucaena leucocephala plants grown in these VFT soils utilized atmospheric- and soilderived $\mathrm{N}$ across all treatments. This invasive legume plant established symbiosis in less acidic soils with intermediate and fast-growing strains from the Mesorhizobium and Rhizobium spp in moderate $\mathrm{N}$ and high $\mathrm{P}$ soils. The non-nodulation and reliance on atmospheric $\mathrm{N}$ of the invasive legume grown in other soil treatments are associated with rhizospheric free-living $\mathrm{N}$-fixing and $\mathrm{N}$-cycling bacteria identified in the experimental soils. This shows that $L$. leucocephala possesses traits that allow it to successfully acquire nutrients, especially in nutrient limited conditions, by investing $C$ resources on below ground biomass, altering $\mathrm{N}$ sources and nutrient assimilation and utilization rates, and establishing symbiosis with nodule forming and non-nodulating endophytic or associative rhizosphere N-fixing bacteria species.

Supplementary Materials: The following are available online at https:/ / www.mdpi.com/article/10 .3390/plants10112242/s1, Supplementary Table S1: Soil characteristics determined from the nutrient addition trials at Ukulinga Farm, KZN. Values represent mean \pm SE, based on $n=4$. Significant differences $(p<0.05)$ among treatments are denoted by different superscript letters. Supplementary Table S2: The molecular identification of soil and plant root nodule isolated nitrogen-fixing bacteria. 
Author Contributions: Conceptualization, A.M. and K.K.; Formal analysis, N.S. and A.M.; Funding acquisition, A.M.; Investigation, N.S., Z.T. and A.M.; N.S. and A.M. prepared the draft manuscript and all authors edited and approved the final version for publication. All authors have read and agreed to the published version of the manuscript.

Funding: This research was funded by the National Research Foundation (NRF), South Africa, grant number UID 113576 and NRF-DSI CoP grant 110768 (Biodiversity assessment as a form of social learning).

Institutional Review Board Statement: Not applicable.

Informed Consent Statement: Not applicable.

Data Availability Statement: All raw data will be avilable upon request from the Dr Anathi Magadlela, the principal investigator of this work and can be contacted at anathimagadlela@icloud.com.

Acknowledgments: We appreciate the assistance of Alison Young and her staff at the Botanical Garden, University of KwaZulu-Natal (Pietermaritzburg, South Africa) during the cultivation of the plants in the greenhouse. In addition, we acknowledge the Central Analytical Facilities at Stellenbosch University and the Archaeometry Department at the University of Cape Town for their research facilities. We appreciated the additional support from these various institutions (University of KwaZulu-Natal, and Stellenbosch University).

Conflicts of Interest: We declare no conflict of interest with regards to this study. The funders had no role in the design of the study; in the collection, analyses, or interpretation of data; in the writing of the manuscript, or in the decision to publish the results. The opinions, findings and conclusions/recommendations expressed in this work are that of the authors, and that NRF accepts no liability whatsoever in this regard.

\section{References}

1. Hughes, C.; Department of Plant Sciences, University of Oxford, Oxford, UK. Compiler: IUCN/SSC Invasive Species Specialist Group (ISSG), Global Invasive Species Database: 2010. Available online: http://www.iucngisd.org/gisd/speciesname/Leucaena+ leucocephala (accessed on 2 April 2014).

2. Olckers, T. Biological control of Leucaena leucocephala (Lam.) de Wit (Fabaceae) in South Africa: A tale of opportunism, seed feeders and unanswered questions. Afr. Entomol. 2011, 19, 356-365. [CrossRef]

3. Henderson, L. Invasive, naturalized and casual alien plants in southern Africa: A summary based on the Southern African Plant Invaders Atlas (SAPIA). Bothalia 2007, 37, 215-248. [CrossRef]

4. Bond, W.J. Ancient grasslands at risk. Science 2016, 351, 120-122. [CrossRef] [PubMed]

5. Duke, J. Handbook of Legumes of World Economic Importance; Springer Science \& Business Media: New York, NY, USA, 2012.

6. Leakey, R.R.; Tchoundjeu, Z.; Schreckenberg, K.; Shackleton, S.E.; Shackleton, C.M. Agroforestry tree products (AFTPs): Targeting poverty reduction and enhanced livelihoods. Int. J. Agric. Sustain. 2005, 3, 1-23. [CrossRef]

7. Craine, J.M.; Morrow, C.; Stock, W.D. Nutrient concentration ratios and co-limitation in South African grasslands. New Phytol. 2008, 179, 829-836. [CrossRef]

8. Sankaran, M.; Ratnam, J.; Hanan, N. Woody cover in African savannas: The role of resources, fire and herbivory. Glob. Ecol. Biogeogr. 2008, 17, 236-245. [CrossRef]

9. Mafongoya, P.; Bationo, A.; Kihara, J.; Waswa, B.S. Appropriate technologies to replenish soil fertility in southern Africa. Nutr Cycl. Agroecosyst. 2006, 76, 137-151. [CrossRef]

10. Bargaz, A.; Drevon, J.-J.; Oufdou, K.; Mandri, B.; Faghire, M.; Ghoulam, C. Nodule phosphorus requirement and $\mathrm{O}_{2}$ uptake in common bean genotypes under phosphorus deficiency. Acta Agric. Scand. Sect. B-Soil Plant Sci. 2011, 61, 602-611. [CrossRef]

11. Ndlovu, J.; Richardson, D.M.; Wilson, J.R.; Le Roux, J.J. Co-invasion of South African ecosystems by an Australian legume and its rhizobial symbionts. J. Biogeogr. 2013, 40, 1240-1251. [CrossRef]

12. Reinhart, K.O.; Callaway, R.M. Soil biota and invasive plants. New Phytol. 2006, 170, 445-457. [CrossRef]

13. Rodríguez-Echeverría, S.; Crisóstomo, J.A.; Nabais, C.; Freitas, H. Belowground mutualists and the invasive ability of Acacia longifolia in coastal dunes of Portugal. Biol. Invasions 2009, 11, 651-661. [CrossRef]

14. Kaschuk, G.; Kuyper, T.W.; Leffelaar, P.A.; Hungria, M.; Giller, K.E. Are the rates of photosynthesis stimulated by the carbon sink strength of rhizobial and arbuscular mycorrhizal symbioses? Soil Biol. Biochem. 2009, 41, 1233-1244. [CrossRef]

15. Magadlela, A.; Pérez-Fernández, M.A.; Kleinert, A.; Dreyer, L.L.; Valentine, A.J. Source of inorganic N affects the cost of growth in a legume tree species (Virgilia divaricata) from the Mediterrean-type Fynbos ecosystem. J. Plant Ecol. 2016, 9, 752-761. [CrossRef]

16. Mortimer, P.E.; Pérez-Fernández, M.A.; Valentine, A.J. Arbuscular mycorrhiza maintains nodule function during external NH 4+ supply in Phaseolus vulgaris (L.). Mycorrhiza 2012, 22, 237-245. [CrossRef]

17. Minchin, F.R.; Witty, J.F. Respiratory/carbon costs of symbiotic nitrogen fixation in legumes. In Plant Respiration; Springer: Dordrecht, The Netherlands, 2005; pp. 195-205. [CrossRef] 
18. Magadlela, A. Variation in Phosphorus Supply Alters Nitrogen Metabolism in the Nodules and Roots of Virgilia Divaricata, a Cape Fynbos Indigenous Legume from the Cape Floristic Region; Stellenbosch University: Stellenbosch, South Africa, 2016.

19. Abbadie, L.; Mariotti, A.; Menaut, J.-C. Independence of savanna grasses from soil organic matter for their nitrogen supply. Ecology 1992, 73, 608-613. [CrossRef]

20. Marchante, E.; Kjøller, A.; Struwe, S.; Freitas, H. Soil recovery after removal of the N 2-fixing invasive Acacia longifolia: Consequences for ecosystem restoration. Biol. Invasions 2009, 11, 813-823. [CrossRef]

21. Stock, W.; Wienand, K.; Baker, A. Impacts of invading N 2-fixing Acacia species on patterns of nutrient cycling in two Cape ecosystems: Evidence from soil incubation studies and $15 \mathrm{~N}$ natural abundance values. Oecologia 1995, 101, 375-382. [CrossRef] [PubMed]

22. Mortimer, P.E.; Le Roux, M.R.; Pérez-Fernández, M.A.; Benedito, V.A.; Kleinert, A.; Xu, J.; Valentine, A.J. The dual symbiosis between arbuscular mycorrhiza and nitrogen fixing bacteria benefits the growth and nutrition of the woody invasive legume Acacia cyclops under nutrient limiting conditions. Plant Soil 2013, 366, 229-241. [CrossRef]

23. Blackburn, T.M.; Pyšek, P.; Bacher, S.; Carlton, J.T.; Duncan, R.P.; Jarošík, V.; Wilson, J.R.; Richardson, D.M. A proposed unified framework for biological invasions. Trends Ecol. Evol. 2011, 26, 333-339. [CrossRef] [PubMed]

24. Macdonald, I.; Reaser, J.; Bright, C.; Neville, L.; Howard, G.; Murphy, S.; Preston, G. Invasive alien species in Southern Africa: National reports and directory of resources. Invasive Alien Species South. Afr. Natl. Rep. Dir. Resour. $2003,125$.

25. Morris, T.L.; Esler, K.J.; Barger, N.N.; Jacobs, S.M.; Cramer, M.D. Ecophysiological traits associated with the competitive ability of invasive Australian acacias. Divers. Distrib. 2011, 17, 898-910. [CrossRef]

26. Lawrie, A. Nitrogen fixation by native Australian legumes. Aust. J. Bot. 1981, 29, 143-157. [CrossRef]

27. Ferguson, B.; Lin, M.-H.; Gresshoff, P.M. Regulation of legume nodulation by acidic growth conditions. Plant Signal. Behav. 2013, 8, e23426. [CrossRef] [PubMed]

28. Lira Junior, M.A. Legume-rhizobia signal exchange: Promiscuity and environmental effects. Front. Microbiol. 2015, 6, 945. [CrossRef]

29. Britto, D.T.; Kronzucker, H.J. NH4+ toxicity in higher plants: A critical review. J. Plant Physiol. 2002, 159, 567-584. [CrossRef]

30. Jebara, M.; Aouani, M.E.; Payre, H.; Drevon, J.-J. Nodule conductance varied among common bean (Phaseolus vulgaris) genotypes under phosphorus deficiency. J. Plant Physiol. 2005, 162, 309-315. [CrossRef] [PubMed]

31. Hellsten, A.; Huss-Danell, K. Interaction effects of nitrogen and phosphorus on nodulation in red clover (Trifolium pratense L.). Acta Agric. Scand. Sect. B-Plant Soil Sci. 2000, 50, 135-142. [CrossRef]

32. Vance, C.P.; Uhde-Stone, C.; Allan, D.L. Phosphorus acquisition and use: Critical adaptations by plants for securing a nonrenewable resource. New Phytol. 2003, 157, 423-447. [CrossRef] [PubMed]

33. Liao, C.; Peng, R.; Luo, Y.; Zhou, X.; Wu, X.; Fang, C.; Chen, J.; Li, B. Altered ecosystem carbon and nitrogen cycles by plant invasion: A meta-analysis. New Phytol. 2008, 177, 706-714. [CrossRef]

34. Van Der Heijden, M.G.; Bardgett, R.D.; Van Straalen, N.M. The unseen majority: Soil microbes as drivers of plant diversity and productivity in terrestrial ecosystems. Ecol. Lett. 2008, 11, 296-310. [CrossRef]

35. Yadav, A.N.; Verma, P.; Singh, B.; Chauhan, V.S.; Suman, A.; Saxena, A.K. Plant growth promoting bacteria: Biodiversity and multifunctional attributes for sustainable agriculture. Adv. Biotechnol. Microbiol. 2017, 5, 1-16. [CrossRef]

36. Elser, J.J.; Bracken, M.E.; Cleland, E.E.; Gruner, D.S.; Harpole, W.S.; Hillebrand, H.; Ngai, J.T.; Seabloom, E.W.; Shurin, J.B.; Smith, J.E. Global analysis of nitrogen and phosphorus limitation of primary producers in freshwater, marine and terrestrial ecosystems. Ecol. Lett. 2007, 10, 1135-1142. [CrossRef]

37. Keerthisinghe, G.; Hocking, P.; Ryan, P.; Delhaize, E. Effect of phosphorus supply on the formation and function of proteoid roots of white lupin (Lupinus albus L.). Plant Cell Environ. 1998, 21, 467-478. [CrossRef]

38. Ward, D.; Kirkman, K.P.; Tsvuura, Z.; Morris, C.; Fynn, R.W. Are there common assembly rules for different grasslands? Comparisons of long-term data from a subtropical grassland with temperate grasslands. J. Veg. Sci. 2020, 31, 780-791. [CrossRef]

39. Mucina, L.; Rutherford, M.C. The Vegetation of South Africa, Lesotho and Swaziland; South African National Biodiversity Institute: Pretoria, South Africa, 2006; p. 807.

40. Bilskie, J.; Scientific, C. Soil Water Status: Content and Potential. Campbell Scientific, Inc. App. Note: 2S-1. 2001. Available online: http:/ / s.campbellsci.com/documents/ca/technical-papers/soilh20c.pdf (accessed on 2 April 2014).

41. Aagot, N.; Nybroe, O.; Nielsen, P.; Johnsen, K. An altered pseudomonas diversity is recovered from soil by using nutrientpoorpseudomonas-selective soil extract media. Appl. Environ. Microbiol. 2001, 67, 5233-5239. [CrossRef]

42. Zungu, N.S.; Egbewale, S.O.; Olaniran, A.O.; Pérez-Fernández, M.; Magadlela, A. Soil nutrition, microbial composition and associated soil enzyme activities in KwaZulu-Natal grasslands and savannah ecosystems soils. Appl. Soil Ecol. 2020, 155, 103663. [CrossRef]

43. Nielsen, K.L.; Eshel, A.; Lynch, J.P. The effect of phosphorus availability on the carbon economy of contrasting common bean (Phaseolus vulgaris L.) genotypes. J. Exp. Bot. 2001, 52, 329-339. [CrossRef]

44. ÅGREN, G.I.; Franklin, O. Root: Shoot ratios, optimization and nitrogen productivity. Ann. Bot. 2003, 92, 795-800. [CrossRef] [PubMed]

45. Mortimer, P.; Archer, E.; Valentine, A. Mycorrhizal C costs and nutritional benefits in developing grapevines. Mycorrhiza 2005, 15, 159-165. [CrossRef] [PubMed] 
46. Peng, S.; Eissenstat, D.M.; Graham, J.H.; Williams, K.; Hodge, N.C. Growth depression in mycorrhizal citrus at high-phosphorus supply (analysis of carbon costs). Plant Physiol. 1993, 101, 1063-1071. [CrossRef]

47. Williams, K.; Percival, F.; Merino, J.; Mooney, H. Estimation of tissue construction cost from heat of combustion and organic nitrogen content. Plant Cell Environ. 1987, 10, 725-734. [CrossRef] 